Short communication

\title{
SCANNING ELECTRON MICROSCOPIC STUDIES OF THE LINGUAL PAPILLAE IN THE ENGLISH HORSE
}

\author{
CAN Mehmet ${ }^{1 *}$, ATALGIN Şükrü Hakan, AYDIN Mehmet Faruk² \\ ${ }^{1}$ Department of Anatomy, Faculty of Veterinary Medicine, University of Balikesir, Balikesir, Turkey; \\ ${ }^{2}$ Department of Histology and Embryology, Faculty of Veterinary Medicine, University of Balikesir, \\ Balikesir, Turkey.
}

(Received 22 October 2015; Accepted 24 February 2016)

The purpose of this study was to describe the distribution and surface structure of the lingual papillary system in four male adult English horses by scanning electron microscopy. The animals were supplied from the Jockey Club of Turkey (TJK). Tissue samples were taken from the dorsal, ventral and lateral surface of the apex, corpus and radix of the tongue. Filiform papillae were distributed mainly on the dorsum, being abundant, very long and with a slim cylindrical form with pointed endings or multi-bifurcated terminations at the apex. These papillae were typically conical in shape with a wider base in the corpus of the lingua and absent on the radix of the lingua. Fungiform papillae were mainly on the lateral surfaces and lobulated forms were also observed. The horses have two large vallate papillae, located on the dorsum close to the caudal part of the tongue. These papillae were surrounded by a prominent gustatory groove. The vallate papillae had many taste pores opening into the papillary groove. The foliate papillae were observed just rostral to the palatoglossal arches. These papillae have many variable sized taste pores which open into the grooves between the papillary leaves. The papillary leaves were covered with concentrically arranged cornified cells of variable appearance. However, there were no lingual papillae on the ventral aspect of the horse's tongue.

Key words: Lingual papillae, English horse, SEM

\section{INTRODUCTION}

The lingual mucosa of mammalian animals is covered with a differentiated papillary system that has mechanical and gustatory functions [1]. The lingual papillary system has been examined by gross anatomy, light microscopy and scanning electron microscopy (SEM). Many morphological studies on the distribution of lingual papillae on the dorsal surface of the tongue have been conducted in mammalian species [2-4]. These morphological studies reported that the characteristics of the tongue in mammalian species are in relation to the lifestyle, diet, and environment in which the mammals live, as well as adaptational and taxonomical features of the animals $[2,3,5,6]$.

\footnotetext{
*Corresponding author: e-mail: mehmetcan4310@hotmail.com
} 
The types of lingual papillae and their distribution have been widely investigated by scanning electron microscopy in various species, including the horse [4], chital deer [6], cattle [7-9], serow [10,11], buffalo [12], Saanen goat [13], camel [14], roan antelope [15], and donkey [16].

Scanning electron microscopic studies of the lingual papillae in equine species were inadequate. Moreover, the types of lingual papillae and their distribution had not been described in the English horse. The purpose of this study was to describe the distribution and surface structure of the lingual papillary system in the English horse by SEM.

\section{MATERIALS AND METHODS}

The tongues of four adult male English horses (10 years old, and with a known pedigree) were used in this study. The weight of the horses was $450 \pm 50 \mathrm{~kg}$ on average. The animals were supplied from the Jockey Club of Turkey (TJK), Bursa, Turkey. Tissue samples were taken from the dorsal, ventral and lateral surface of the apex, body and root of the tongue. Small pieces of tissue from the fixed tongues were cut, rinsed in $0.1 \mathrm{M}$ phosphate buffer ( $\mathrm{pH} 7.2$ ) and fixed again in $2.5 \%$ glutaraldehyde in $0.1 \mathrm{M}$ phosphate buffer $(\mathrm{pH} 7.2)$ for $2 \mathrm{~h}$ at room temperature. The specimens were washed several times in $0.1 \mathrm{M}$ phosphate buffer $(\mathrm{pH} 7.2)$. After dehydration through a graded ethanol series they were infiltrated with hexamethyldisilasin (HMDS). For SEM, the material was fixed on aluminum stubs using double-sided adhesive. The SEM micrographs were taken on a SEM-JEOL, (JCM 5000) at an accelerating voltage of $10-15 \mathrm{kV}$.

Anatomical terms were used in agreement with the Nomina Anatomica Veterinaria [17].

\section{RESULTS AND DISCUSSION}

The English horse tongue is a slender, mobile muscular organ $12-20 \mathrm{~cm}$ in length with a comparatively smooth surface. A characteristic median groove was seen clearly on the dorsum, particularly at the apex of the tongue. On the dorsal surface of the lingual mucosa, filiform, vallate, foliate and fungiform papillae were determined. However, lentiform papillae were not described. The ventral surface of the tongue was covered with a smooth mucosa and mechanical or gustatory papillae were not described.

The filiform papillae are mechanical papillae of the lingual papillary system. These papillae differed mainly in form and abundance along different parts of the tongue. On the apex of the lingua, the filiform papillae were abundant very long, slim, and with a cylindrical form with pointed endings or multi-bifurcated terminations (Fig. 1). The apical parts of these papillae were sometimes twisted and their roots were covered with keratinocytes. On the corpus of the lingua, the filiform papillae were typically conical in shape with a wider base coated with keratinocytes (Fig. 2). On the radix 
of the lingua, the filiform papillae were absent. On the lateral surfaces of the corpus lingua, short, few and sparsely distributed filiform papillae were described. However, on the ventral aspect of the tongue, filiform papillae were not described (Fig. 3). On the radix of the lingua many taste pores were observed.

The vallate papillae which are gustatory papillae were the largest of all papillae types. Horses have two large vallate papillae, located on the dorsum close to the caudal part of the tongue. These papillae were surrounded by a prominent gustatory groove (Fig. 4). The vallate papillae had many taste pores opening into the papillary groove (Fig. 5). Fine filiform papillae were not described on the bulb-like part of the vallate papillae.
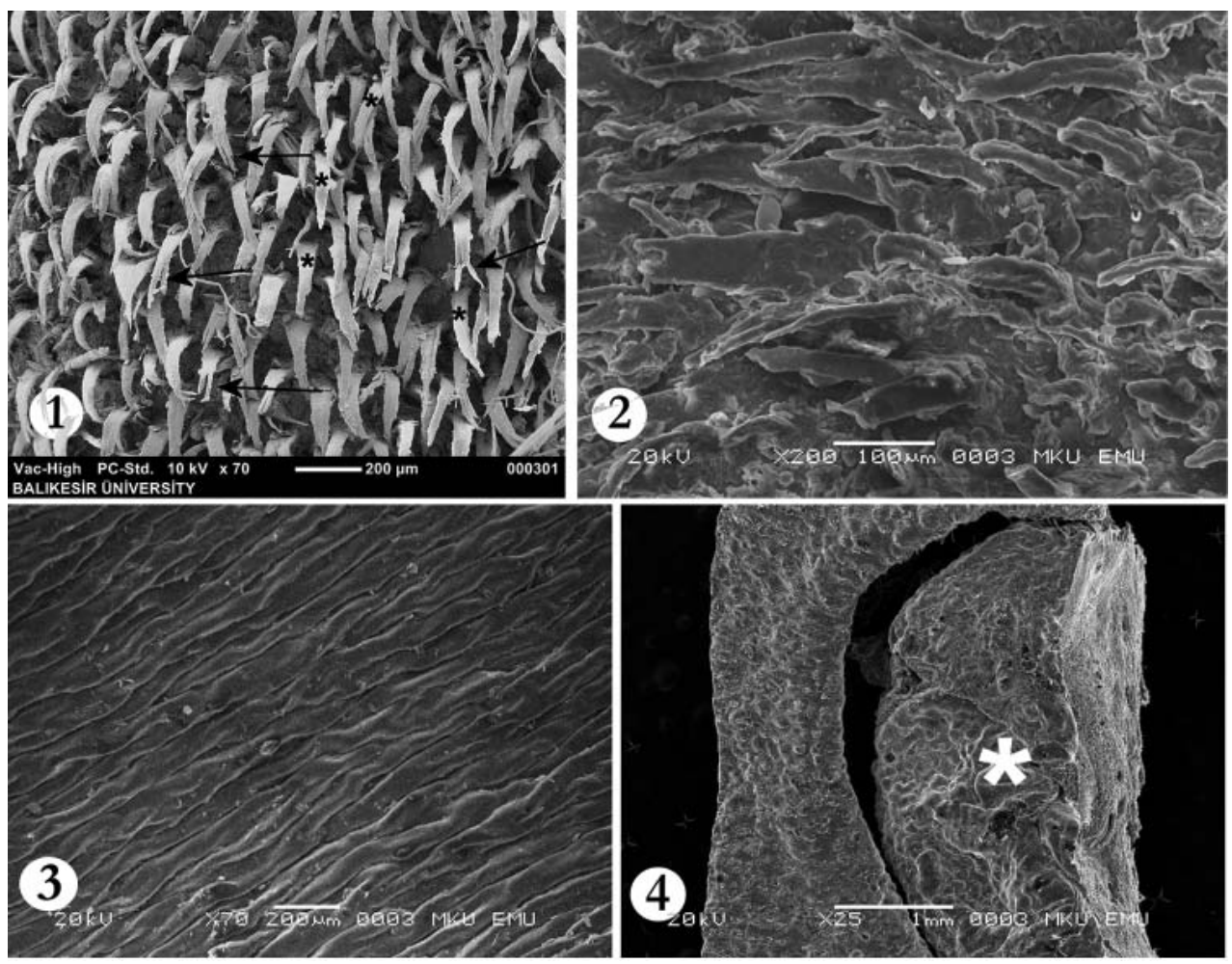

Figure 1. SEM micrograph of the lingual apex, the filiform papillae are abundant, very long and with a slim cylindrical form with pointed endings (asterisks) or multi-bifurcated terminations (arrows).

Figure 2. SEM micrograph of the corpus of the lingua, the filiform papillae have a typical conical shape with a wider base.

Figure 3. Ventral aspect of the tongue, filiform papillae were not described.

Figure 4. Vallate papillae (asterisk) were surrounded by a prominent gustatory groove.

The foliate papillae are gustatory papillae of the lingual papillary system. These papillae were observed just rostral to the palatoglossal arches in the form of serially arranged leaves, separated by grooves. These papillae had many variable sized taste 
pores which were opening into the grooves between the papillary leaves (Fig. 6). The papillary leaves were covered with concentrically arranged cornified cells of variable appearance (Fig. 7).

Fungiform papillae which were distributed sporadically were seen among numerous filiform papillae. Fungiform papillae were observed mainly on the lateral aspects of the tongue. However these papillae were in reduced numbers on the dorsum of the tongue. They were mostly rounded with an elevated convex surface and a lobulated form with partially divided shallow grooves. Fungiform papillae were covered with numerous short rodshaped filiform papillae (Fig. 8). These papillae did not emerge from the surface of the tongue. No taste buds were seen in the fungiform papillae.
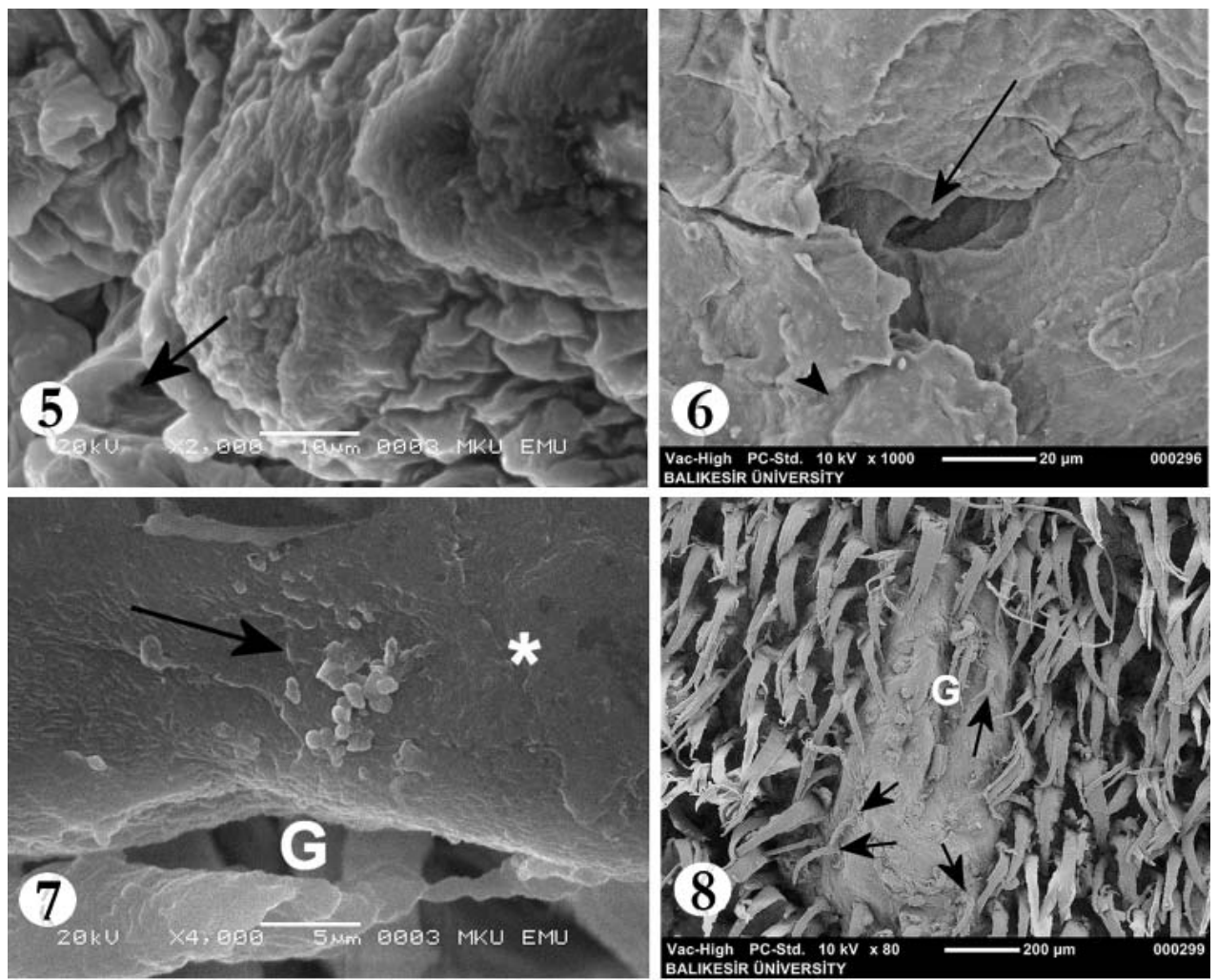

Figure 5. The vallate papillae had many taste pores (arrow).

Figure 6. SEM micrograph of the foliate papillae taste pores (arrow).

Figure 7. SEM micrograph of the foliatae papillary leaf (asteriks) are covered with concentrically arranged cornified cells of variable appearance. G: Groove.

Figure 8. Fungiform papillae are mostly rounded with an elevated convex surface and a lobulated form with partially divided shallow grooves $(\mathrm{G})$. Fungiform papillae are covered with numerous short rodshaped filiform papillae (arrows).

Scanning electron microscopic studies of the lingual papillae in equine species have been remarkably limited in spite of the importance of this species both historically 
and in modern times. In the present study we provided additional information on the types of lingual papillae and their distribution on the horse tongue. Our data demonstrated greater variations in shape, as well as in the terminal splitting of the filiform papillae, in contrast to earlier preliminary data reported for the horse [18]. Our data state that the filiform papillae on the lingual apex are abundant, very long and with a slim cylindrical shape with pointed endings or multi-bifurcated terminations were similar to Pfeiffer et al. [19]. Similar findings were also reported by Kobayashi et al. [4].

Although filiform papillae in the horse are very slender and of a very pliable appearance, the filiform papillae of cattle [20] and goats [21] consist of a thick main process with small accessory processes. That the filiform papillae of the horse are of a very thin and slender shape with no small accessory processes. It seems that they are very pliable compared to cattle and goats. In addition, filiform papillae found in cattle and goats may facilitate a much stronger chewing power than the very slender papillae of horses. Structural differences of the filiform papillae might have evolved relative to the different functional roles of these two species. In the horses' situation, the grass is cut by incisor teeth close to the ground; the filiform papillae may play a relatively minor mechanical role. However, the bovine tongue is used more prehensively to rip and ingest longer grass at a longer distance off the ground and more severe mechanical stresses would be placed upon the caudal portion of the tongue.

The number and distribution of the vallate papillae have shown some differences among species. They are single in the rat and hamster [22,23], double in horses [8], several in dogs [23]. Moreover, ruminant species have shown a relatively large number of vallate papillae; in cattle [8,20], goats [24], sheep [25], buffalo [26] and camel [27].

The equine tongue was reported to have one pair of vallate papillae [8]. Our findings were similar to Chamorro et al. [8] and Kobayashi et al. [4], and these two papillae were located on the dorsum close to the caudal part of the tongue. However, El Sharaby et al. [26] found an additional papilla in the middle of the tongue in the donkey as reported by Abd- Elnaeim et al. [16].

Fungiform papillae which were distributed sporadically among the filiform papillae were present mainly on the lateral aspects of the tongue. However these papillae were in reduced numbers on the dorsum of the tongue. Our findings were similar to Pfeiffer et al. [19]. Parallel to Kobayashi et al. [4] we observed that the fungiform papillae are covered with numerous short rodshaped filiform papillae. In our study, no taste buds were seen in the fungiform papillae. Similar findings were also reported by Abd- Elnaeim et al. [16]. However, taste buds had been seen by Chamorro et al. [8].

The horses had a pair of prominent foliate papillae which were seen as well developed on each side of the tongue. Foliate papillae are not present in carnivores such as dogs [28], and typical grasseating animals such as cattle and goats. However primitive animals like rodents such as the rat [30], rabbit and guinea pig [31] also have foliate papillae. Chamorro et al. [8] in horses and Abd- Elnaeim et al. [16] in donkeys reported 
on the existence of deep grooves separating each papillary leave and the large number of taste pores located deep in these grooves could explain their remarkable gustatory function. Our results supported Chamorro et al. [8] and Abd- Elnaeim et al. [16].

It was thought that the presence of well developed foliate papillae in equine species might substitute the presence of few vallate papillae. Considering the structure of the filiform papillae and the number of vallate papillae and other characteristics, the tongue of the horse has a moderate mechanical and a well developed gustatory capability.

\section{Authors' contributions}

All authors equally contributed to this work, read and approved the final manuscript.

\section{Declaration of conflicting interests}

The author(s) declared no potential conflicts of interest with respect to the research, authorship, and/or publication of this article.

\section{REFERENCES}

1. Adnyane IKM, Zuki AB, Noordin MM, Agungpriyono S. Morphological study of the lingual papillae in the Barking deer, Muntiacus muntjak. Anat. Histol. Embryol 2011; 40: $73-77$.

2. Iwasaki S. Evolution of the structure and function of the vertebrate tongue. Journal of Anatomy 2002; 201: 1-13.

3. Jackowiak H and Godynicki S. The scanning electron microscopic study of lingual papillae in the silver fox (Vulpes vulpes fulva, Desmarest, 1820). Annals of Anatomy 2004; 186: 179-183.

4. Kobayashi K, Jackowiak H, Frackowiak H, Yoshimura K, Kumakura M. Comparative morphological study on the tongue and lingual papillae of horses (Perissodactyla) and selected ruminantia (Artiodactyla). Italian Journal of Anatomy and Embryolology 2005; 110: 55-63.

5. Erdogan S, Alan A. Gross anatomical and scanning electron microscopic studies of the oropharyngeal cavity in the European magpie (Pica pica) and the common raven (Corvus corax). Microscopy Reseach and Technique 2012; 75: 379-387.

6. Erdogan S, Perez W. Anatomical and scanning electron microscopic studies of the tongue and lingual papillae in the chital deer (Axis axis, Erxleben 1777). Acta Zoologica (Stockholm) 2014; 95: 484-492.

7. Steiflek DE, Singh BB, McKenney RV, Boshell JL. Correlated TEM, SEM and histological observations of filiform papillae of the cow tongue.. Acta Anat 1983;17: 21-30.

8. Chamorro CA, de Paz P, Sandoval J, Fernandez JG. Comparative scanning electronmicroscopic study of the lingual papillae in two species of domestic mammals (Equus caballus and Bos taurus). I Gustatory papillae. Acta Anat 1986;125: 83-87. 
9. Scala G, Mirabella N, Pelagalli GV. Etude morphofunctionnelle des papilles linguales chez le boeuf (Bos taurus). Anat Histol Embryol 1995;24: 101-105.

10. Funato H, Atoji Y, Suzuki. Morphological studies on the tongue of wild Japanese serows, Capricornis crispus. Res Bull Fac Agr Gifu Univ 1985; 50: 205-219.

11. Atoji Y, Yamamoto Y, Suzuki Y. Morphology of the tongue of a male formosan serow (Capricornis crispus swinhoei). Anat Histol Embryol 1998; 27: 17-19.

12. Scala G, Pelagalli GV, Vittoria A. Etude morpho-structurale des papilles linguales chez le buffle (Bubalus bubalis). Anat Histol Embryol 1993; 22: 264-272.

13. Kurtul I, Atalgin SH. Scanning electron microscopic study on the structure of the lingual papillae of the Saanen goat. Small Rum Res 2008; 80: 52-56.

14. Quayyum M, Fatani JA, Mohajr AM. Scanning electron microscopic study of the lingual papillae of the one humped camel, Camelus dromedarius. J Anat 1998; 160: 21-26.

15. Emura S, Okumura T and Chen H. Morphology of the lingual papillae in the roan antilobe. Okajimas Folia Anat Jpn 2011; 88 (3): 127-131.

16. Abd-Elnaeim MM, Zayed AE, Leiser R. Morphological characteristics of the tongue and its papillae in the donkey (Equus asinus): a light and scanning electron microscopical study. Ann Anat 2002; 184: 473-480.

17. NAV 2005 Nomina Anatomica Veterinaria, International Committee on Veterinary Gross Anatomical Nomenclature, 5th Ed. Gent, Belgium.

18. De Paz Cabello PCA, Chamorro J Sandoval, M Fernandez. Comparative scanning electron microscopic study of the lingual papillae in two species of domestic mammals (Equus caballus and Bos taurus) II. Mechanic papillae. Acta Anat 1998; 132: 120-123.

19. Pfeiffer C J, Levin M, Lopes MAF. Ultrastructure of the Horse Tongue Further Observations on the Lingual Integumentary Architecture. Anat Histol Embryol 2000; 29: 37-43

20. Asami Y, Asami T and Kobayashi K Light Microscopic and scanning electron microscopic studies on the lingual papilla and structure of their connective tissue cores in cattle. Shigaku (Odomology) 1995; 82: 1223-1244.

21. Inatorn M And Kobayashi K. Comparative Morphological studies on the tongue and lingual papillae of the japanese black bear (carnivora) and the mountain goat (Artiodactyla). Shi-gaku (Odomology) 1999; 87: 313-382.

22. Iwasak S, Yoshizawa H, Kawahara I. Study by scanning electron microscopy of the morphogenesis of three types of lingual papilla in the rat. Anat Rec 1997; 247: 528-541.

23. Ashraf A, El Sharaby Samir A, El-Gendy Mohamed A Alsafy, Ahmed G. Nomir, Satoshi Wakisaka. Morphological variations of the vallate papillae in some mammalian species. Anat Sci Int 2014; 89: 161-170.

24. Kumar P, Kumar S, Singh Y. Tongue papillae in goat: a scanning electron-microscopic study. Anat Histol Embryol 1998; 27: 355-357.

25. Emura, S, Tamada, A, Hayakawa, D. Morphology of the dorsal lingual papillae in the Barbary sheep. Ammotragus lervia. Okajimas Folia Anat Jpn. 2000; 77(2-3): 39-45.

26. El Sharaby AA, El-Gendy SA, Alsafy MA, Nomir AG, Wakisaka S. Morphological variations of the vallate papillae in some mammalian species. Anat Sci Int 2014; 89: 161-170.

27. El Sharaby AA, Alsafy MA, El-Gendy SA, Wakisaka. Morphological characteristics of the vallate papillae of the one humped camel (Camelus dromedarius). Anat Histol Embryol 2012; 41(6): 402-409. 
28. Kobayaski K, Miyata K, Takahashi K, Iwasaki S. Developmental and morphological changes in dog lingual papillae and their connectivetissue papillae. In: Inoue et el. (eds). Proceedings 6'h M: Singer Symposium, 1988a; 609-617.

29. Lino T, Kobayashi K. Morphological studies on the lingual papillae and their connective tissue papillae of rat. Odontology 1988c: 75; 1039-1060.

30. Kobayashi K. Three-dimensionel architecture of the connective tissue core of the lingual papillae in the guinea pig. Anat Embryol 1990: 205; 205-213.

\title{
IZUČAVANJE PAPILA NA JEZIKU ENGLESKOG PUNOKRVNOG KONJA POMOĆU ELEKTRONSKE MIKROSKOPIJE
}

\author{
CAN Mehmet, ATALGIN Şükrü Hakan, AYDIN Mehmet Faruk
}

Cilj ove studije je bio da se elektronskkom mikroskopijom opišu distribucija i struktura površine lingvalnog papilarnog sistema kod četiri odrasla pastuva rase engleski punokrvnjak. Životinje je obezbedio “Jockey Club of Turkey (TJK)".Uzorci tkiva uzeti su sa dorzalne, ventralne i lateralne površine vrha, tela i korena jezika. Filiformne papile su bile raspoređene prvenstveno dorzalno. Bile su brojne, dugačke, tankog i cilindričnog oblika, šilatog vrha ili sa višestrukim račvama na apeksu. Ove papile su tipično bile konusnog oblika sa širom osnovom na telu jezika, dok su bile odsutne sa korena jezika. Pečurkaste papile su uočene na lateralnim delovima gde su uočeni i lobulaarni oblici. Konji poseduju i dve opšančene papile smeštene na dorzumu bliže kaudalnom delu jezika. Ove papile su okružene uočljivim gustativnim šancem. Opšančene papile poseduju mnogobrojne pore u papilarnom šancu. Listaste papile su uočene rostralno u odnosu na palatoglosalne lukove. Ove papile poseduju pore različitih veličina čiji su otvori između listova papila. Papilarni listovi su pokriveni koncentrično aranžiranim kornifikovanim ćelijama varijabilnog izgleda. Nije zabeleženo prisustvo papila na ventralnoj strani jezika konja. 